\title{
Police Brutality in Post-Apartheid South Africa Reviewed
}

\author{
Zondi ZV \\ Ukpere WI \\ Department of Industrial Psychology and People Management, Faculty of Management, \\ University of Johannesburg, Johannesburg, South Africa \\ E-mail: wikpere@uj.ac.za
}

\section{Doi:10.5901/mjss.2014.v5n3p574}

\section{Abstract}

The objective of this paper was to revisit the issue of police brutality in post-apartheid South Africa, since it has recently become a highly contextual topic with polarising views. Some individuals have tried to justify the level of brutality by the South African Police Service, while others disagree with these views and perceive the issue as problematic. Apart from the literature review, questionnaires where formulated distributed to twenty individuals from the general public, in order to ascertain their perception regarding the issue. This questionnaire was structured in a way that would allow the individuals to not only state their opinion regarding the different aspects of the South African Police Service but to also enable the respondent to elaborate on their reasoning. The finding from the feedback obtained from ten respondents reveal that police brutality is perceived as a major problem in South Africa, and most individuals are perturb by the current state of affairs. However, they feel very helpless in their ability to change the situation. Some respondents feel that it is only people in top positions in the police hierarchy or government that could influence the change that is required to improve the situation, in order to enhance the image of the South African Police Services, in such a way that communities could perceive them more as friends rather than enemies.

Keywords: Abuse, Authority, Brutality, Crime, Constitution, Law enforcement, Public Order, SAPS, Society

\section{Introduction and Background}

Historically the use of police force in South Africa has always been to provide a service to the public, which is in line with the South African government 's Batho Pele ( People first) initiative to improve the delivery of public services (Van Graan \& Ukpere, 2012; Makda, Bayat \& Ukpere, 2012). This service would include crime prevention, community policing, crime stop as well as ensuring the safety of the general public in matters such as strikes or any protests that may affect society. The vision and mission of the South African Police Services as stated in the Constitution of the Republic of SA 1996 ( act 108 of 1996) which states that the SAPS is responsible for :

- Maintaining public order

- Upholding and enforcing the law

- Ensuring that criminals are brought to justice

- The Preventing, combating and investigating crime

- Participation in efforts to address the causes of crime

- Investigating any crimes that threaten the safety or security of any community

- Preventing anything that may threaten the safety and security of any community

- Creating a safe and secure environment of all people in South Africa

- Protecting the inhabitants of the republic and their property

The SAPS has always been viewed as a law enforcement body that has been put in place to protect the needs of the general public from young child up to the oldest grey hairs of our society. They have been greatly respected and praised as a means of refuge for the abused, mistreated and those whose rights have been violated. The SAPS has been recognised as an integral part of society to all communities in the furthest stretch of the South African Landscape (Brogden \& Shearing, 1993).

However, in some not distance past the police force under the apartheid regime was known for extreme violence and unfairness in its approach to uphold the law, where some individuals of certain group were exempted from their unlawful behaviours while others were extensively abused or killed for petty crimes. During this period the police were greatly feared and disliked as they only served a specific group and did not cater to the ordinary man on the street 
(Cawthra, 1994).

At the end of apartheid in the 1994 and the triumph of democracy in South Africa, the South African Police service underwent reform and was taken over by different management, which totally changed the manner in which the South African Police Service was viewed by the South African citizens. A few years after the great effort to change the image of the South African Police service there has been a noticeable switch in the manner in which the SAPS has been viewed as a result of noticeable incidences of police brutality (Bruce, 2002).

\section{Problem Statement}

There has been a noticeable occurrence of police brutality in South Africa.

\section{Research Questions}

The problem statement mentioned above has led to the following research questions:

- Is police brutality a serious problem in South Africa?

- What factors contribute to police brutality?

- How does police brutality affect society's view of the police force?

- How can police brutality be reduced?

- Whose responsibility is it to manage or control the behaviour of the SAPS

\section{Research Objectives}

The following are the objectives of this research paper:

- To examine the seriousness of the problem of police brutality in South Africa

- To identify factors that contribute to police brutality

- To identify how the brutality of the police force affect the manner in which society views the police force as a whole

- To investigate measures/steps that can be taken in order to reduce police brutality

- To identify whose responsibility it is to manage or control the behaviours of the SAPS

\section{Literature Review}

In the first place, it is imperative to establish what exactly police brutality is. Based on literatures it was found that police brutality can be expressed in different forms and is usually physical. However, a high level of police brutality is in the form of false arrests, intimidation, verbal attacks, police corruption and many other forms of inappropriate behaviour by member of the police personnel.

USLegal (2014) defines police brutality as "a civil right violation that occurs when a police officer acts with excessive force by using an amount of force with regards to a civilian that is more than necessary". USlegal (2014) further maintained that, "excessive force is not subject to precise definition, but that it is generally beyond the force a reasonable and prudent law enforcement officer would use under the circumstances".

Police brutality is found in all parts of the globe including USA, Britain, India, Nigeria and South Africa. However, for the purpose of this study, the focus will be on South Africa. Cawthra (1994), while highlighting issues relating to the transformation before the advent of Democracy, provides evidence and data of the deaths, brutality as well as the hope for a new South Africa, and expressed his viewpoint of how the South African Police services is an important part in changing or moving away from the role it played during the apartheid era. Further literature provided more insight with regards to the way the Police services was geared during the apartheid era and how there is a difference between police forces in an autocratic and democratic country and the level of accountability in a variety of areas including internal police systems as well as civil society to mention a few. Based on the literatures, it was observed that although the levels of accountability have increased in the South African Police Service since 1994, the SAPS still needs to do more in order to achieved its mandate after the dawn of democracy in South Africa.

Marks (2007), examines how South Africa is the only country in Southern Africa that is enabling unions and labour rights to exist within the South African police force, as a result, this is leading to much instability within the South African Police Service, which in turn affects the general public. 
Raf Casert (2013) describes the most recent public police brutality of a Mozambican immigrant, which lead to the death of the immigrant. The article highlighted the events that transpired on the 26 February 2013 when Mido Macia was allegedly obstructing traffic on the East Rand near Daveyton with his vehicle which struck the attention of the South African Police officers. When the officers approached Macia, he allegedly assaulted the constable and took his weapon. The article further describes how Mido Macia was than brutally abused by the Police officers. According to sources, which was aired in several social media and News channels, the Police officers allegedly bound Macia's hands on the rear of the police van and then sped off, dragging the slender taxi driver along the pavement. This article exposes how the South African police Service have yet again expose their level brutality to the very people that they are supposed to protect. The police officers who were dressed in full police uniform and driving a registered and marked police vehicle abused their power and held total disregard for the exact law they were expected to uphold and defend. According various sources, Mido Macia was taken to the Daveyton police station where he lay there for hours bleeding to death in a cell without any medical attention. His alleged crime was refusing to obey police officers who ordered him to stop blocking traffic with his vehicle.

The Daily sun newspaper also posted a video footage Thursday $28^{\text {th }}$ February on their website www.dailysun.co.za which sparked a great deal of outrage regarding South African police brutality. The National Police commissioner Riah Phiyega "Strongly condemned" what happened. Riah also urged South Africans to remain vigilant and continue to report all acts of crime irrespective of who is involved.

De Vos, (2013) addresses the issue of police brutality. He made reference to a statement by the deputy minister of safety and security, on 9 April 2008 encouraging the police force to kill the bastards (criminals) if they threatened communities. She further told the police force not to worry about regulations and assured the police station commissioners and policemen and women from community areas that they have permission to kill criminals. This article further explains how soon after that there was a proposal to amendments section 49 of the criminal procedure act, the legal provision dealing with the use of lethal force for arrest" in order to make it easier for the South African police service to shoot and kill people suspected by the police of being involved in crime.

De Vos (2013) basically highlights the various statements made by prominent South figures that encourage the excessive use of force by the Police service in total disregard for the fact that members of the South African Police Service are required to operate within the confines of the law in the execution of their duties. The Marikana Massacre is still very fresh in the mind of people. Hamilton (2012) re-enacted the events that unfolded on that day the 16 August 2012 in which 34 striking lonmin miners were massacred. It all started as a strike by the lonmin miners related to wage increase demands. When their demand was not heeded to, these employees resorted to strike action, which became deadly.

Hamilton (2012), describes Lonmin Company which runs the mine as having a strong pedigree of brutality in the virtual police state it has established on its mines. Private security forces and the police serve the mining bosses, who act with impunity. Weizmann (2012) further explained that the deaths that occurred before the massacre which claimed the lives of the six workers, two policeman and two security guards as well two workers were the direct result of the culture of violence that the company has cultivated over the years.

Hamilton (2012) article suggests the opposite of what had been revealed at the commencement of the trial later held regarding the blood bath of the lonmin workers on the 16 August 2012, which suggest that the police actually acted in self-defence. He further explained what have emerged from what transpired on that faithful day is that the main massacre occurred 300 metres from the site television cameras were trained on and there was evidence that the workers were shot execution style as they raised their hands to surrender or on the back as they fled. This finding seems to contradict the position of the police service that the workers were shot as they were armed and attacking the police, which then lead to the police protecting themselves by means of excessive force. However, Hamilton (2012) further posited that a decision had been made to drown the strike in blood. This decision could not have been concluded by lonmin management or police alone but government must have been consulted at the highest level as lonmin management does not have enough power to conclude matters on such a high degree without the knowledge or consent of a higher power even though the matter concerned their workers.

In recent publication on police brutality statistics Du Plessis (2012) of the Independent police investigative directorate (IPID) indicated that 720 deaths or fatal incidents in the 2011/2012 financial year with 232 of all fatalities were deaths in police custody, while 488 were as a result of police action. He mentioned that although this was a 10 per cent reduction from the previous year it was still a number that raised considerable concern.

Hosken (2011) investigates the reasons why South African police Officers are so brutal. In his article, he identifies poor training, negligent police management, criminal members within the police force, disrespect for the law and order, 
as well as disregard for internal disciplinary procedure as the main causes for the increasing police brutality that is affecting the South African police Services. He further addressed the issues that were highlighted by the Independent complaints Directorate as well as the renowned South African criminologists' conference held in Pretoria in the month of March 2011, on which platform the matter of police brutality was discussed. With an estimated 2464 criminal complaints laid against the police in the year 2009/2010 financial year, the ICD and criminologists requested an urgent action to curb this crisis. According to the statistics released by the ICD, of the 2464 complaints rate, 17 percent were for attempted murder, 22 percent was for common assault, and 40 percent were for assault with the intent to cause grievous bodily harm (ibid). This article further posited that of all deaths through police action, 46 percent were during arrests, 22 percent occurred during the commission of crimes, 4 percent during escapes and 2 percent consist of those killed as innocent bystanders (ibid).

An attendee at the forum, David Bruce, who is a senior researcher at the centre for the study of violence and reconciliation, expressed concerns that usually the use of force is often completely unnecessary, especially as the police involved had alternate ways of dealing with the situations. He averred that there is a clear responsibility that the police management has in creating a clear policy regarding the use of force, as it had been in some occasions noticed that the policemen acted in good faith but due to lack of skills and experience, the use of force resulted to more harm.

Hosken (2011) gave a detailed statistics of abuse and unnecessary force by the police force as well as the necessary steps that should be undertaken by the police management with great supervision by the Independent complaints Directorate, in order to ensure a reduction in of police brutality. Mail\&Guardian (2011) reported an incident of police brutality that claimed the life of an innocent citizen, Jeanette Odendaal aged 45 outside the Kempton park police station. Which took place when Jeanette Odendaal crashed into a stationer police vehicle, while Sipho Baloyi a car guide was helping her to park. It was alleged that the police officer came around from the charge office, he did not say anything but walked to the passenger's window and shot Odendaal in the arm (ibid). Baloyi who witnessed this pleaded with the officer to call emergency services but the officer refused claiming that she is already dying and that there is no point to call an ambulance. When other members of the police services rush down to the scene and inquire why he had shot Odendaal, the officer advised that he had mistook the noise of the crash for gunshots (Mail\&Guardian, 2011). Although the police officer was later arrested, but once again, an innocent person's life was extinguished at the hands of the very person who was supposed to save and protect her life.

Williams (2012) observed that police brutality cases are not properly probed. This fact finding research suggests that there are areas in which police report late or decide not to report at all certain cases which is actually a violation of section 29 of the IPID act. Another article narrated other cases related to police abuse of power including allegations that 12 officers from Bellville organised crime unit had tortured, assaulted and murdered 24 year old Sidwell Mkwambi (Dolley, 2009). In North West, five members of the Klerksdorp Organised crime unit were in court over reports that they tortured alleged bank robbers in 2010. Another mentioned case in the article was that of police officers that were captured on cctv footage beating patrons at a tavern in Wallacedene in the Western cape in early 2010. Although there were many incidents mentioned in this article by Williams (2012), his article further observed that even though allegations of torture or assault were lodged the chances that they would be investigated to the full might of the law and prosecuted were quiet low.

\section{Research Methodology}

This paper mainly relied on secondary data. This study is based on conceptual analysis as well as "Emic" perspective. The main source of data obtained was by means of online articles as well as newspaper regarding the subject matter. Questionnaires were also formulated and handed out to twenty individuals of the general public to answer questions regarding how they personally felt about police brutality. This questionnaire covered areas such as the degree to which these individuals feel that police brutality in South Africa is an actual matter of concern, whether they feel safe and protected by the SAPS, if the recent events relating to police brutality has influenced the level of trust and faith they have in the South African Police authorities as well as what they think should and can be done to curb this increasing problem .This research method was best because it provided the researcher with updated information of recent incidents relating to Police Brutality as well as provided the views of group of other people that come from different ethnic backgrounds and communities. 


\subsection{The limitation of research}

The main limitations were that the subject or research topic information was mainly obtainable via articles. However few books where actually published regarding this topic as compared to other generalist topics or even organisation or company related matters (e.g. Job satisfaction ) which limited me to online articles, newspapers and videos.

\subsection{Research methodology contributions/success}

The main ability to track various data that was published regarding Police Brutality from various sources highlighted the mental state of the authors during the time of the edition of the article. The graphic content in most of this publications made understanding the actual article and author's viewpoint more understandable. The ability to track the views and opinions of members of the general public by means of a questionnaire added value to the research. The fact that this topic is currently on the lips of many South Africans especially as a result of the recent incidences that have taken place in the past few months, made it easy to obtain current publications on the topic.

\section{Analysis and Findings}

- Since the fall apartheid regime, the level of Police Brutality has reduced. However it is still very present in the police force, hence the ICD was put in place as a measures to try and reduce this excessive behaviour of some police officers. However, there is still more work that needs to be done to ensure the accountability of the police force in the manner they execute their duties.

- There are various factors that have contributed to police brutality, such as the increased rate of police murders by criminals as well as the instruction given from the top ministerial level that has encouraged police to utilise excessive force.

- The South African police force seems to carry the legacy of apartheid in which the use of extensive force was a norm.

- Although the South African police Force is not as brutal as it used to be during the apartheid regime, there is certainly still a matter of great concern in the level of brutality that is being used by some police officers.

- Some ministers have upset the efforts to improve the behaviours of the SAPS by making statements that seemingly encourage the poor and unacceptable behaviours of the some Police officers.

- The rate of deaths as a result of police action has been noted to have reduced only by 10 per cent from the previous year. The level of accuracy in this number is uncertain as not all incidents of police brutality are recorded.

- Some of the factors that have led to police brutality are the feeling by the SAP officers that they always need to resort to excessive force in order to execute their duties as well as the opinion that they are the law rather than representatives of the law.

\section{Recommendations and Conclusions}

- There is an urgent need to intensify the monitoring of police behaviour by the top management and institutions such as the Independent complaints directorate (ICD), in order to redress the abuse of power by some members of the police force. The belief that they are the law rather than upholders of the law is should be made right.

- More academic training should be given to personnel during the orientation phase of their recruitment into the police service on how to deal with the general public on matters that could bring down the image of the force. Personnel should be fully versed on the full content of their jobs, their responsibilities, their accountabilities and what wearing a Police uniform actually represents with special emphasis on the consequences of not abiding by these standards.

- Society's confidence and trust in the South African police service seems to have been eroded by the negative behaviour of some personnel in the force. Some section now perceive police personnel as people who disregard the law rather than uphold it. Therefore, most of the officers who behave in this negative way should be forced to undertake a course in organisational behaviour or be forced out of the force.

- Police brutality can be reduced by greater intervention by the ICD as well as continuous mentoring of new 
recruits. A greater level of accountability should be placed on the SAPS personnel. A clear document outlining the behaviours that are acceptable or unacceptable in the force should be written and signed by each police officer, so that they may be held accountable to their signed commitments.

- The South African Police Service should not only be obliged to report deaths (as per their current requirements) but should also be required to report on all assaults or torture and lack of evidential support. This will assist in adjusting the behaviours of the SAPS.

- Another way in which South Africa could hold the South African Police officers (who may misbehave) accountable is by means of judicial commissions of inquiry into any noticeable form of abuse and deaths as well as investigations by the national human rights commission, which has the power of doing extensive investigations into varied issues including police brutality. These could help to redress the current level of police brutality in South Africa.

\section{References}

Brogden, M \& Shearing C (1993). Policing for a New South Africa. London: Routledge Press.

Bruce D (2002). New Wine from an old Cask? The South African Police Service and the process of Transformation. Johannesburg: Centre for the Study of Violence and Reconciliation.

Cawthra, G. (1994). Policing South Africa. London: Zed Books Ltd.

Casert, R (2013,). Police brutality: South African Police drag man, who later dies". The Daily sun newspaper 27 February 2013. [Online] Available: http://www.Dailysun.co.za [Retrieved on 02 March 2013].

De Vos,P (2013). Outcry about police brutality sheer hypocrisy. [Online] Available: http://www.constitutionalityspeaking.co.za [Retrieved on 10 March 2013].

Dolley C (2009). 15 Elite officers face murder probe. The Star, 3 April 2009. [Online] Available: http://www.security.co.za Ifullstory.asp?Newsld=12148

Du plessis, C. (2012). Deaths in police Custody down. City press newspaper. [Online] Available: http://www.citypress.co.za [Retrieved on 13 January 2013].

Hamilton.W (2012) Marikana Massacre ignites the mass movement. [Online] Available: http://www.socialistworld.net/doc/5957 [Retrieved on 19 February 2013]

Hosken, G.(2011). Why SA cops are so brutal. [Online] Available: http://www.iol.co.za/news/crime-courts/why-sa-cops-are-so-brutal1.1074181 [Retrieved on 25 May 2013].

Mail\&Guardian (2011). Report of police brutality are isolated case. [Online] Available: http://mg.co.za/article/2011-04-28report-of-policebrutality-are-isolated-incident [Retrieved on 18 January 2014].

Makda T, Bayat S, Ukpere WI. 2012. Risk Management within the events industry in Cape Town South Africa. African Journal of Business Management, 6(20):6243-6253.

Marks M (2007). Police as Workers: Police labour rights in southern Africa and beyond

USLegal (2014). Police brutality Law \& Legal definition [Online] Available: http://definitions.uslegal.com/p/police-brutality/ [Retrieved on 18 January 2014].

Van Graan J, Ukpere WI. 2012. The role of Impact Evaluation on Service Delivery within the Public Sector Organizations. African Journal of Business Management, 6(39):10445-10457.

William, D. (2012) Police brutality cases not properly probed. [Online] Available: http://www.sowetanlive.co.za/news/2012/06/05/policebrutality-cases-not-properly-probed [Retrieved 13 February 2013]. 